\section{A Mutation That Causes Lability of the Androgen Receptor under Conditions That Normally Promote Transformation to the DNA-binding State}

William J. Kovacs, James E. Griffin, David D. Weaver, Barbara R. Carlson, and Jean D. Wilson Department of Internal Medicine, The University of Texas

Health Science Center at Dallas, Southwestern Medical School, Dallas, Texas 75235; Department of Medical Genetics, Indiana University Medical School, Indianapolis, Indiana 46223

suggest that dihydrotestosterone may amplify the androgenic signal at its targets not only by its higher affinity for the receptor but also by its more efficient conversion to the DNA-binding state and that such amplification may be less critical in target tissues in which testosterone suffices for androgenic effect. This offers one possible explanation of how a mutation that affects a single receptor protein may differentially impair the actions of two binding ligands of the receptor. with syndromes of androgen resistance. In contrast to the situation with dihydrotestosterone, normal testosteronereceptor complexes are unstable under in vitro transforming conditions. Although equal amounts of hormonereceptor complex are formed at $0^{\circ} \mathrm{C}$, only $15 \%$ of testosterone-receptor complexes remain stable and acquire DNA-binding capacity after warming. This instability is not reversible upon lowering the temperature and is corrected by low concentrations $(0.25 \mu \mathrm{M})$ of the protease inhibitor leupeptin. We have also identified two cousins with androgen resistance whose androgen-receptor complexes exhibit similar in vitro transformation lability with both dihydrotestosterone and testosterone. Phenotypic evidence in these subjects indicates that dihydrotestosterone-mediated processes are more completely impaired than are testosterone-mediated events. These findings

This work has been published in abstract form (Clin. Res. 31:471, 1983). Dr. Kovacs was the recipient of a postdoctoral fellowship under training grant AM07307. 1983.

Received for publication 13 July 1983 and in revised form 20 December

J. Clin. Invest.

(c) The American Society for Clinical Investigation, Inc. $0021-9738 / 84 / 04 / 1095 / 10 \quad \$ 1.00$

Volume 73, April 1984, 1095-1104

\section{Introduction}

The syndromes of androgen resistance are characterized by normal or greater than normal production of testicular androgens but ineffective action of these hormones in target tissues. The clinical spectrum of these disorders ranges from complete failure of male phenotypic development (complete testicular feminization) to isolated defects of spermatogenesis in otherwise normal men (1). In vitro correlates of these phenotypes have been studied in cultured skin fibroblasts, and some of the defects in androgen action have been characterized. Known abnormalities include quantitative deficiencies of androgen binding, qualitative abnormalities thought to result from structural alterations in the receptor, and a few instances in which the androgen receptor appears to be normal in amount and function, implying an abnormality in some subsequent step in androgen action (1).

To provide additional insight into the events in androgen action that follow binding of the steroid to the receptor we have recently examined in vitro the process termed "transformation" by which androgen-receptor complexes of human fibroblast cytosol acquire the capacity to bind to DNA (2). The transformation of steroid-receptor complexes to the DNA-binding state is thought to be a necessary step in steroid hormone action. The chemical nature of this reaction is unknown, but it appears to involve a conformational change in the receptor protein that results in an alteration in net charge and permits the receptor- 
hormone complex to bind to polyanionic substances such as DNA (3).

We report here comparative studies of the ability of testosterone-receptor and dihydrotestosterone-receptor complexes from normal cytosol to undergo transformation to the DNAbinding state. In addition, we have studied the transformation phenomenon in fibroblasts from subjects with androgen resistance in whom the amount of cytosolic receptor is sufficient to allow measurement of binding of the hormone-receptor complexes to DNA. We have identified a subset of subjects with qualitatively abnormal androgen receptors in whom the androgen-receptor complex is unstable under transforming conditions. The defect in these subjects appears to impair dihydrotestosterone-mediated events more severely than testosteronemediated processes.

\section{Methods}

Materials. $\left[1,2,4,5,6,7^{3} \mathrm{H}\right]$ Dihydrotestosterone (17 $\beta$-hydroxy- $5 \alpha$-androstan-3-one) and $\left[1,2,4,6,7^{3} \mathrm{H}\right]$ testosterone were from New England $\mathrm{Nu}$ clear (Boston, MA). Nonradioactive steroids were from Steraloids Inc. (Wilton, NH). Crystallized bovine serum albumin was from Reheis Co. (Phoenix, AZ). Sodium molybdate, aprotinin, phenylmethylsulfonyl fluoride, pepstatin, bacitracin, leupeptin, and highly polymerized calf thymus DNA were from Sigma Chemical Co. (St. Louis, MO). Specially washed cellulose was from P-L Biochemicals Inc. (Milwaukee, WI). Sephadex G-25 was from Pharmacia Fine Chemicals (Piscataway, NJ).

Buffers. The following buffers were used: TE $(20 \mathrm{mM}$ Tris $\mathrm{HCl}$ and $1 \mathrm{mM}$ EDTA, pH 7.15) ${ }^{1} ; 20 \mathrm{mM}$ Tris $\mathrm{HCl}, 1 \mathrm{mM}$ EDTA, and $1 \mathrm{mM}$ mercaptoethanol, pH 7.15; TEGM $(20 \mathrm{mM}$ Tris $\mathrm{HCl}, 1 \mathrm{mM}$ EDTA, $1 \mathrm{mM}$ mercaptoethanol, and $10 \%$ glycerol volume per volume, $\mathrm{pH}$ 7.15); TEGM- 10 (TEGM containing $10 \mathrm{mM} \mathrm{NaCl}$ and $0.2 \mathrm{mg} / \mathrm{ml}$ bovine serum albumin); TEGM containing $300 \mathrm{mM} \mathrm{NaCl}$ and $0.2 \mathrm{mg} / \mathrm{ml}$ bovine serum albumin. The $\mathrm{pH}$ of all buffers was adjusted at room temperature $\left(23^{\circ} \mathrm{C}\right)$, and the buffers were stored and used at $0^{\circ} \mathrm{C}$.

Cell culture. Fibroblasts were grown as described (4) from explants of genital skin obtained at circumcision or from biopsies. After monolayer cultures became confluent (day 6 after plating) the standard medium was changed to medium without added serum, and the experiments were performed $1 \mathrm{~d}$ later.

The cell strains used in these experiments were all derived from labia majora, foreskin, or scrotum and are listed in Table I. The cell strains included two control strains previously used in this laboratory (strains 43 and 457) (5), two control strains from boys with panhypopituitarism (strains 62 and 486), four strains from boys with sporadic perineoscrotal hypospadias of unknown etiology (strains 32, 49, 496, and 498), and six strains from subjects with measurable amounts of androgen receptor despite the clinical features of androgen resistance. The six strains so designated (Nos. 321, 18, 79, 500, 16, and 512) included three previously described subjects in whom the androgen receptor is normal by the criteria used previously in this laboratory (strains 321 ,

1. Abbreviations used in this paper: TE buffer, $20 \mathrm{mM}$ Tris $\mathrm{HCl}$ and 1 mM EDTA, pH 7.15; TEGM buffer, $20 \mathrm{mM}$ Tris $\mathrm{HCl}, 1 \mathrm{mM}$ EDTA, $1 \mathrm{mM}$ mercaptoethanol, and $10 \%$ glycerol volume per volume, $\mathrm{pH} 7.15$; TEGM-10, TEGM containing $10 \mathrm{mM} \mathrm{NaCl}$ and $0.2 \mathrm{mg} / \mathrm{ml}$ bovine serum albumin; Tris-saline, $20 \mathrm{mM}$ Tris- $150 \mathrm{mM} \mathrm{NaCl}$.
18 , and 79) and three (strains 16,500 , and 512) in which the androgen receptor is qualitatively abnormal (5).

Strain 500 was from a 4-yr-old, 46,XY patient of Dr. David Brown of the University of Minnesota, Minneapolis; the boy had microphallus, perineoscrotal hypospadias, and cryptorchidism, normal response of plasma androgens to human chorionic gonadotropin, and normal $5 \alpha$ reductase activity in cultured skin fibroblasts. The high affinity androgen receptor is normal in amount but is qualitatively abnormal as evidenced by a failure of molybdate to stabilize the $8 \mathrm{~S}$ receptor complex on sucrose density gradients (5) (Table I).

Cell strain 16 was derived from a labia majora biopsy of $46, \mathrm{XY}$ infant (subject MW) who was evaluated by two of us (Drs. Carlson and Weaver) at 1 mo of age. On physical examination the child was found to have a small phallus $(1 \mathrm{~cm})$ and a bifid scrotum with palpable testes. The urethral opening was on the perineum. After an human chorionic gonadotropin stimulation test (2,000 $\mathrm{U}$ daily for $3 \mathrm{~d}$ ) plasma testosterone rose to $462 \mathrm{ng} / \mathrm{dl}$. A female sex assignment was agreed upon by parents and physicians. At surgery, normal epididymides and vasa deferentia were identified, and no mullerian structures were found. Bilateral gonadectomy and inguinal herniorrhaphy were performed. The microscopic examination of the resected tissues showed normal testes, epididymides, and vasa deferentia. On the basis of the clinical findings, a diagnosis of male pseudohermaphroditism due to androgen resistance was made. A maternal cousin with an apparently identical phenotype had been born 3 yr earlier; labia majora biopsy was subsequently obtained on this subject as well (strain 512).

Monolayer binding assays. On the day of the experiment the monolayers of fibroblasts (6-cm diam. wells) were rinsed with $2 \mathrm{ml}$ of media without serum and incubated at $37^{\circ} \mathrm{C}$ for $60 \mathrm{~min}$ with media containing various concentrations $(0.2-3.0 \mathrm{nM})$ of $\left[{ }^{3} \mathrm{H}\right]$ dihydrotestosterone. The cells were rinsed, harvested with trypsin-EDTA, and sonicated. Aliquots were taken for measurement of radioactivity and protein. Total dihydrotestosterone binding was plotted as a function of steroid concentration, and $B_{\max }$ or amount of high-affinity binding was calculated as before (4) by extrapolating the plateau portion of the binding curve to the ordinate. Experiments in which thermolability was assessed in monolayers were similar except that incubations were carried out at both $37^{\circ}$ and $42^{\circ} \mathrm{C}$. All media and dishes were separately incubated at these temperatures. A $>40 \%$ decrease in $B_{\max }$ at $42^{\circ}$ relative to $37^{\circ} \mathrm{C}$ was considered evidence for thermolability $(5,6)$. Intranuclear localization of $\left[{ }^{3} \mathrm{H}\right] \mathrm{di}-$ hydrotestosterone in monolayers of intact cells was assessed by a procedure previously described (7) except that a single saturating concentration of ligand was used for estimation of total and nonspecific binding. DNA was measured by the method of Kissane and Robbins (8).

Preparation of cytosol. Confluent monolayers of cells (in 15-cm dishes) were washed twice with $4 \mathrm{ml}$ of ice-cold $20 \mathrm{mM}$ Tris- $150 \mathrm{mM} \mathrm{NaCl}$ (Tris-saline) and harvested by scraping with a rubber policeman in 4 $\mathrm{ml}$ of the same solution. The pooled cells were pelleted by centrifugation at $480 \mathrm{~g}$ for $4 \mathrm{~min}$ at $4^{\circ} \mathrm{C}$. The pellet was washed with two more times with Tris-saline and once with $20 \mathrm{mM}$ Tris $\mathrm{HCl}, 1 \mathrm{mM}$ EDTA, and 1 $\mathrm{mM}$ mercaptoethanol, $\mathrm{pH}$ 7.15. The cell pellet was suspended in an equal volume of TEGM containing $5 \mathrm{mM} \mathrm{Na}_{2} \mathrm{MoO}_{4}$ and homogenized in a glass Dounce homogenizer on ice with 15 strokes of the tight pestle. The homogenate was diluted as needed for various experiments with TEGM + $5 \mathrm{mM} \mathrm{Na}_{2} \mathrm{MoO}_{4}$ and centrifuged at $100,000 \mathrm{~g}$ for $60 \mathrm{~min}$. The supernatant from this centrifugation was used for all studies of the cytosolic androgen receptor. Protein concentration in the cytosol averaged $2-4 \mathrm{mg} / \mathrm{ml}$.

Androgen binding assays in cytosol. Stock solutions of radioactive and nonradioactive steroids were prepared and stored in ethanol. Purity 
of radioactive steroids was $>95 \%$ as assessed by thin-layer chromatography. For binding assays, aliquots of stock solutions were added to glass tubes and taken to dryness under vacuum. The tubes were then placed on ice and cytosol was added.

Cytosol was incubated at $0^{\circ} \mathrm{C}$ for $3 \mathrm{~h}$ with either $\left[{ }^{3} \mathrm{H}\right]$ dihydrotestosterone or $\left[{ }^{3} \mathrm{H}\right]$ testosterone in various concentrations, and parallel incubations were carried out with a 500 -fold excess of nonradioactive hormone to estimate nonspecific binding. Three different binding assays gave similar results for both total and nonspecific binding.

(a) Dextran-coated charcoal assay. Aliquots of cytosol containing radioactive steroid $(0.2 \mathrm{ml})$ were mixed with $50 \mu$ l of a charcoal-dextran slurry ( $50 \mathrm{mg}$ charcoal and $5 \mathrm{mg}$ dextran T-70 per milliliter of TE buffer) to remove unbound hormone. The tubes were stirred and promptly centrifuged at 2,000 rpm for $10 \mathrm{~min}$. Aliquots of the supernatant were added to $10 \mathrm{ml}$ of scintillation mixture (Budget-Solve, Research Products International, Mount Prospect, IL) and assayed for radioactivity. Protein concentration in the cytosol was estimated by the method of Lowry et al. (9), using bovine serum albumin as standards.

(b) Hydroxylapatite assay. Aliquots $(0.5 \mathrm{ml})$ of a $50 \%$ suspension of washed hydroxylapatite in TEGM containing $5 \mathrm{mM} \mathrm{Na}_{2} \mathrm{MoO}_{4}$ were added to $0.2-\mathrm{ml}$ aliquots of cytosol containing radioactive steroid. The mixture was kept at $0^{\circ} \mathrm{C}$ for $30 \mathrm{~min}$ and stirred every $10 \mathrm{~min}$. The tubes were centrifuged at $480 \mathrm{~g}$ for $5 \mathrm{~min}$ and the supernatant was discarded. The hydroxylapatite pellets were washed three times with $2 \mathrm{ml}$ of TEGM containing $5 \mathrm{mM} \mathrm{Na}_{2} \mathrm{MoO}_{4}$ and $0.5 \%$ Triton $\mathrm{X}-100$. After the final wash the hydroxylapatite pellet was extracted with $1 \mathrm{ml}$ of $100 \%$ ethanol for $30 \mathrm{~min}$ at room temperature. After centrifugation, aliquots of the supernatant were assayed for radioactivity.

(c) Gel filtration. Aliquots of cytosol containing radioactive steroid $(0.2 \mathrm{ml})$ were applied to $5-\mathrm{ml}$ columns (bed volume) of Sephadex G-25 equilibrated with TEGM. The columns were eluted with TEGM, and five drop fractions were collected in minivials. Scintillation mixture $(3.5 \mathrm{ml})$ was added to each vial, and the samples were assayed for radioactivity. The sum of radioactivity eluting in the void volume of the column was computed. Nonspecific binding was estimated in samples incubated with a 500-fold excess of nonradioactive hormone.

Sucrose density gradient centrifugation. Aliquots $(0.2 \mathrm{ml})$ of cytosol that had been incubated for $3 \mathrm{~h}$ at $0^{\circ} \mathrm{C}$ with $\left[{ }^{3} \mathrm{H}\right]$ dihydrotestosterone were treated with charcoal as above and applied to continuous gradients $(4.9 \mathrm{ml})$ of $5-20 \%$ sucrose in TEGM. Some gradients also contained $10 \mathrm{mM} \mathrm{Na}_{2} \mathrm{MoO}_{4}$ or $0.3 \mathrm{M} \mathrm{KCl} .\left[{ }^{14} \mathrm{C}\right]$ Acetylated albumin $(\simeq 1,000 \mathrm{dpm})$ prepared by the method of Montelaro and Rueckert (10) was used as an internal marker on the gradients. The tubes were centrifuged at $250,000 \mathrm{~g}$ for $18 \mathrm{~h}$ at $0^{\circ} \mathrm{C}$ in a Beckman ultracentrifuge (Beckman Instruments, Inc., Palo Alto, CA) using the SW50.1 rotor. The gradients were fractionated from the top into four drop aliquots using an ISCO gradient fractionator (Instrumentation Specialties Co., Inc., Lincoln, $\mathrm{NE}$ ), and each fraction was assayed for radioactivity in $10 \mathrm{ml}$ of scintillation mixture. In some experiments the gradients contained $3 \mathrm{nM}$ $\left[{ }^{3} \mathrm{H}\right]$ dihydrotestosterone, and the cytosol was not charcoal treated before centrifugation. In these experiments, bound steroid in each fraction of the gradient was estimated by the hydroxylapatite assay described above.

DNA-cellulose binding assay. DNA-cellulose (1-2 mg of DNA per packed milliliter of cellulose) was prepared by the method of Alberts and Herrick (11) and stored at $-20^{\circ} \mathrm{C}$ in TE buffer containing $150 \mathrm{mM}$ $\mathrm{NaCl}$. Denatured DNA was used, as previous experiments showed slightly more binding of receptor to denatured DNA than to the native form (2). Aliquots were thawed as needed for use. The binding assay was carried out in a cold room at $0^{\circ} \mathrm{C}$. DNA-cellulose was diluted to a thin slurry with TEGM-10, packed in 1-ml glass syringes to a bed volume of $0.4 \mathrm{ml}$, and washed with TEGM-10. Aliquots of cytosol $(0.2 \mathrm{ml})$ that had been incubated with ${ }^{3} \mathrm{H}$-steroid and subjected to various transforming procedures were applied to the columns. The DNA-cellulose was washed with $\sim 30$ bed volumes of TEGM-10 until a constant background of radioactivity $(<90 \mathrm{dpm} / 0.5 \mathrm{ml})$ was attained in the eluate. The $\left[{ }^{3} \mathrm{H}\right]$ hormone-receptor complexes were eluted with five successive aliquots $(0.5 \mathrm{ml})$ of TEGM containing $300 \mathrm{mM} \mathrm{NaCl}$ and $0.2 \mathrm{mg} / \mathrm{ml}$ bovine serum albumin. Scintillation mixture $(10 \mathrm{ml})$ was added to each vial, and the samples were assayed for radioactivity. The radioactivity eluting from the column in the high salt wash was summed as a measure of transformed receptor bound to the DNA. In parallel experiments in which aliquots of cytosol were incubated with ${ }^{3} \mathrm{H}$-steroid plus a 500 fold excess of nonradioactive steroid, no adherence of radioactivity to the DNA was observed.

Thin-layer chromatography. Thin-layer chromatography was performed as before (6) to assess any metabolism of steroids during the various assays.

\section{Results}

\section{Transformation of androgen-receptor complexes}

In previous studies we characterized the transformation of dihydrotestosterone-receptor complexes from fibroblast cytosol to the DNA-binding state. When receptor-hormone complexes were prepared in buffers containing from 0.5 to $10.0 \mathrm{mM}$ sodium molybdate and saturating concentrations of $\left[{ }^{3} \mathrm{H}\right]$ dihydrotestosterone the complexes remained in the nontransformed state (unable to bind to DNA) as long as the cytosol was kept at $0^{\circ} \mathrm{C}$. Upon warming to $25^{\circ} \mathrm{C}$ the complexes acquired DNAbinding capacity in a time-dependent fashion. Higher concentrations of molybdate prolong the time course but do not prevent transformation at $25^{\circ} \mathrm{C}(2)$.

When binding of $\left[{ }^{3} \mathrm{H}\right]$ testosterone and $\left[{ }^{3} \mathrm{H}\right]$ dihydrotestosterone in cytosol are compared at $0^{\circ} \mathrm{C}$ similar amounts of saturable high-affinity binding are seen, but dihydrotestosterone binds to the receptor with an affinity severalfold higher than that of testosterone (Fig. 1, $A$ and $B$ ). Dihydrotestosterone-receptor complexes remained stable upon heating at $25^{\circ} \mathrm{C}$ for 1 $\mathrm{h}$, and a significant proportion ( $58 \%$ in this experiment) was transformed to the DNA-binding state (Fig. 2). In contrast, $\left[{ }^{3} \mathrm{H}\right]$ testosterone-receptor complexes formed at $0^{\circ} \mathrm{C}$ become unstable when heated at $25^{\circ} \mathrm{C}$ in the presence of saturating concentrations of ligand, and less DNA-binding capacity is generated (14\% of original receptor content) (Fig. 2). Thin-layer chromatography of extracts from these incubations showed that $<10 \%$ of the radioactive testosterone and dihydrotestosterone were metabolized during the experiment (results not shown). $\left[{ }^{3} \mathrm{H}\right]$ Dihydrotestosterone was used in the subsequent studies because it appears to be a more favorable ligand for the generation of transformed androgen-receptor complexes.

Transformation of dihydrotestosterone-receptor complexes in controls and patients with androgen resistance

We utilized molybdate-stabilized cytosol in the standard DNAcellulose binding assay to investigate transformation of $\left[{ }^{3} \mathrm{H}\right]-$ 


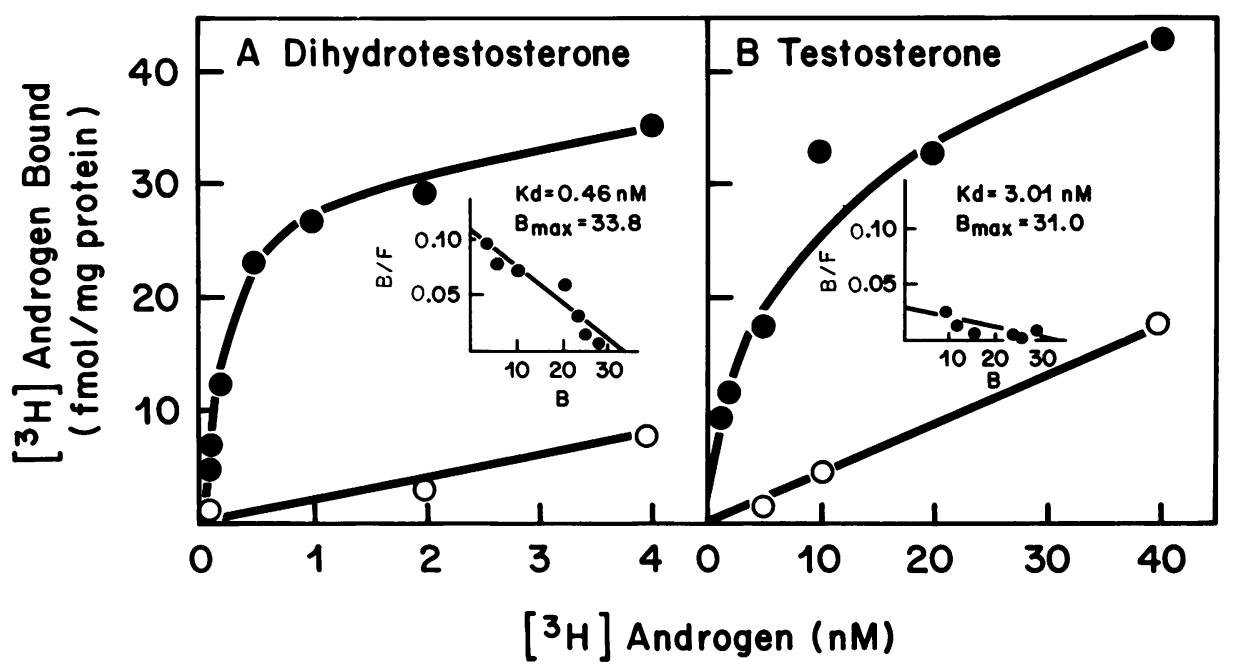

Figure 1. Binding of androgens by normal human fibroblast cytosol. Cytosol was prepared in TEGM buffer with 5.0 $\mathrm{mM}$ sodium molybdate. $0.2-\mathrm{ml}$ aliquots were incubated with various concentrations of either dihydrotestosterone $(A)$ or testosterone $(B)$ with and without a 500 -fold excess of nonradioactive hormone. After $3 \mathrm{~h}$ of incubation at $0^{\circ} \mathrm{C}$ the cytosol was assayed for $\left[{ }^{3} \mathrm{H}\right]$ androgen binding by the hydroxylapatite method. $\bullet$, total binding; $O$, nonspecific binding. Scatchard analysis of the data is shown in the insets. dihydrotestosterone-receptor complexes from various fibroblast strains. Studies of the transformation of androgen-receptor complexes of fibroblast cytosol from normal controls, boys with perineoscrotal hypospadias of unknown etiology, and subjects with well-defined syndromes of androgen resistance are summarized in Table $I$. The selection of mutant strains was, of necessity, limited to those having sufficient quantities of specific $\left[{ }^{3} \mathrm{H}\right]$ dihydrotestosterone binding in cytosol at $0^{\circ} \mathrm{C}$ to allow study of DNA binding. At $3 \mathrm{nM}$ dihydrotestosterone the specific $\left[{ }^{3} \mathrm{H}\right]$ dihydrotestosterone binding in cytosol averaged $\sim 30 \mathrm{fmol} /$ $\mathrm{mg}$ protein in the four normal control strains and in the four strains from boys with hypospadias. Furthermore, the receptor

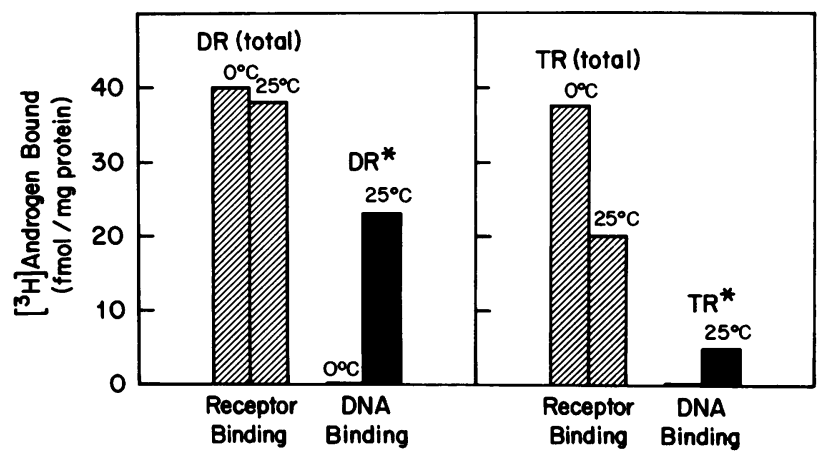

Figure 2. Heat-induced transformation of dihydrotestosterone and testosterone-receptor complexes. Cytosol was prepared from normal fibroblasts and incubated for $3 \mathrm{~h}$ at $0^{\circ} \mathrm{C}$ with either $1.5 \mathrm{nM}$ $\left[{ }^{3} \mathrm{H}\right]$ dihydrotestosterone (left) or $15 \mathrm{nM}\left[{ }^{3} \mathrm{H}\right]$ testosterone (right). Parallel incubations contained a 500 -fold excess of nonradioactive hormone to estimate nonspecific binding. After the $0^{\circ} \mathrm{C}$ incubation, samples were warmed at $25^{\circ} \mathrm{C}$ for $1 \mathrm{~h}$. The total amount of androgen specifically bound to receptor (DR and TR) was estimated by gel filtration after the $0^{\circ}$ and $25^{\circ} \mathrm{C}$ incubation. The amounts of transformed hormone-receptor complexes (DR* and $\left.\mathrm{TR}^{*}\right)$ were estimated by the DNA-cellulose binding assay. in these eight control strains appeared to be qualitatively normal by the criteria previously used in this laboratory, namely no thermolability of androgen binding in monolayers and stability upon ultracentrifugation when molybdate was included in the homogenization buffer (5).

Several subjects with androgen resistance associated with normal binding in intact monolayer assays but qualitative receptor defects detected by sucrose density gradient centrifugation (5) were found to have receptors that were unstable when broken cell preparations were made in molybdate-containing buffers even at $0^{\circ} \mathrm{C}$, and thus were unsuitable for further studies of transformation. However, six individuals with endocrine evidence of androgen resistance had suitable receptors for the assessment of DNA binding (Table I). This group included three subjects $(500,16$, and 512$)$ with qualitative abnormalities of the androgen receptor (failure of molybdate stabilization) and three subjects with no identified abnormality of the androgen receptor $(321,18$, and 79) (7). Transformation of androgenreceptor complexes was normal in four of the six subjects, i.e., $58-83 \%$ of the receptor bound to DNA-cellulose after incubation at $25^{\circ} \mathrm{C}$ (Table I). Cytosol from two cell strains from one family (16 and 512) showed defective transformation of $\left[{ }^{3} \mathrm{H}\right]$ dihydrotestosterone-receptor complexes to the DNA-binding state. We characterized this defect in detail in strain 16.

Characterization of the androgen receptor from the subject with defective transformation

Studies on intact cells. In fibroblast monolayers the amount of high affinity binding approximated $33 \mathrm{fmol} / \mathrm{mg}$ protein in strain 16 , well within the normal range of $18-50 \mathrm{fmol} / \mathrm{mg}$ protein $(5$, 6 ), and the dissociation constant estimated from the binding curve for $\left[{ }^{3} \mathrm{H}\right]$ dihydrotestosterone was $0.15 \mathrm{nM}$ (normal range $0.1-0.3 \mathrm{nM}$ ). When binding studies were carried out in intact cells at two temperatures $\left(37^{\circ}\right.$ and $\left.42^{\circ} \mathrm{C}\right)$, no difference in the amount of high affinity $\left[{ }^{3} \mathrm{H}\right]$ dihydrotestosterone binding was detected (data not shown). The intracellular localization of 
Table I. Heat-induced Transformation to the DNA-binding State of Skin Fibroblast Androgen-receptor Complexes from Controls and Subjects with Receptor-positive Androgen Resistance

\begin{tabular}{|c|c|c|c|c|c|c|c|c|}
\hline \multirow{3}{*}{ Diagnosis } & \multirow{3}{*}{$\begin{array}{l}\text { Cell } \\
\text { strain }\end{array}$} & \multirow{3}{*}{ Site of biopsy } & \multirow{3}{*}{$\begin{array}{l}\text { Age } \\
y r\end{array}$} & \multicolumn{5}{|c|}{ Characteristics of the androgen receptor } \\
\hline & & & & \multirow[t]{2}{*}{$\begin{array}{l}\text { Thermolability } \\
\text { in monolayers }\end{array}$} & \multirow[t]{2}{*}{$\begin{array}{l}\text { Failure of } \\
\text { molybdate } \\
\text { stabilization }\end{array}$} & \multirow{2}{*}{$\begin{array}{l}\text { Specific dihydrotes- } \\
\text { tosterone binding in } \\
\text { cytosol, } 0^{\circ} \mathrm{C}\end{array}$} & \multicolumn{2}{|c|}{$\begin{array}{l}\text { Dihydrotestosterone- } \\
\text { receptor complex binding } \\
\text { to DNA cellulose, } 25^{\circ} \mathrm{C}\end{array}$} \\
\hline & & & & & & & fmol/mg protein & $\%$ \\
\hline \multicolumn{9}{|l|}{ Controls } \\
\hline \multirow[t]{4}{*}{ Normals } & 43 & Foreskin & 26 & no & no & 21.6 & 11.2 & 52 \\
\hline & 62 & Scrotum & 9 & no & no & 23.0 & 13.0 & 56 \\
\hline & 457 & Scrotum & 21 & no & no & 26.9 & 19.8 & 74 \\
\hline & 486 & Scrotum & & no & no & 32.3 & 19.1 & 59 \\
\hline \multirow{4}{*}{$\begin{array}{l}\text { Perineoscrotal hypospadias } \\
\text { of unknown etiology }\end{array}$} & 32 & Scrotum & 0.5 & no & - & 29.4 & 17.8 & 59 \\
\hline & 49 & Foreskin & 1 & no & no & 32.5 & 24.2 & 74 \\
\hline & 496 & Scrotum & 1 & no & no & 36.0 & 19.5 & 54 \\
\hline & 498 & Scrotum & 2 & no & no & 47.0 & 35.3 & 75 \\
\hline \multicolumn{9}{|l|}{ Androgen resistance syndromes } \\
\hline \multirow[t]{4}{*}{ With normal transformation } & 321 & Labia majora & 16 & no & no & 8.8 & 7.1 & 84 \\
\hline & 18 & Foreskin & 18 & no & no & 28.9 & 18.8 & 65 \\
\hline & 79 & Labia majora & 14 & no & no & 32.8 & 27.3 & 83 \\
\hline & 500 & Scrotum & 4 & no & yes & 20.4 & 11.8 & 58 \\
\hline \multirow{2}{*}{$\begin{array}{l}\text { With defective } \\
\text { transformation }\end{array}$} & 16 & Labia majora & 0.1 & no & yes & 18.1 & 0.6 & 3 \\
\hline & 512 & Labia majora & 4 & no & yes & 9.8 & 1.5 & 16 \\
\hline
\end{tabular}

Heat-induced transformation of androgen-receptor complexes to the DNA-binding state was assessed by DNA-cellulose binding assay in fibroblast cytosol from five normal controls, four subjects with perineoscrotal hypospadias of unknown etiology and six subjects with androgen resistance but measurable amounts of cytosolic androgen receptor. Cell strains are identified by diagnosis, age of subject, and site of biopsy as well as presence (yes) or absence (no) of two markers of qualitative abnormality of the androgen receptor (thermolability in intact cell monolayers and failure of molybdate stabilization on sucrose density gradient centrifugation). Data are expressed as amount of specific binding at $3 \mathrm{nM}$ $\left[{ }^{3} \mathrm{H}\right]$ dihydrotestosterone $\left[\mathrm{Bs}\left(0^{\circ} \mathrm{C}\right)\right]$ and as the amount and percentage of cytosolic hormone-receptor complexes binding to DNA after $\left(25^{\circ} \mathrm{C}\right)$ heating.

Table II. Intracellular Localization of Bound $\left[{ }^{3} \mathrm{H}\right]$ Dihydrotestosterone in Fibroblasts from a Control Subject and the Subject with Failure of Heat-induced Transformation of the Androgen Receptor to the DNA-binding State

\begin{tabular}{|c|c|c|c|c|}
\hline Strain & Site & $\mathbf{B}_{\mathbf{T}}$ & B $_{\text {Ns }}$ & Bs $_{\mathbf{s}}$ \\
\hline & & \multicolumn{3}{|c|}{$\mathrm{fmol} / \mu \mathrm{g} D N A$} \\
\hline \multirow[t]{2}{*}{ Control (457) } & Whole cell & 5.9 & 1.85 & 4.05 \\
\hline & Nucleus & 2.3 & 0.12 & $2.18(54 \%)$ \\
\hline \multirow[t]{2}{*}{ Mutant (16) } & Whole cell & 3.9 & 1.50 & 2.40 \\
\hline & Nucleus & 1.4 & 0.12 & $1.28(53 \%)$ \\
\hline
\end{tabular}

Intact monolayers of fibroblasts were incubated at $37^{\circ} \mathrm{C}$ with $3 \mathrm{nM}$ $\left[{ }^{3} \mathrm{H}\right]$ dihydrotestosterone for $1 \mathrm{~h}$. The monolayers were washed, and the cells were harvested with trypsin. Whole cell $\left[{ }^{3} \mathrm{H}\right]$ dihydrotestosterone binding and nuclear uptake of $\left[{ }^{3} \mathrm{H}\right]$ dihydrotestosterone were measured by the method of Collier et al. (7), and DNA was determined on aliquots of each sample. $\mathrm{B}_{\mathrm{T}}$, Total binding; $\mathrm{B}_{\mathrm{NS}}$, nonspecific binding, and $\mathrm{B}_{\mathbf{S}}$, specific binding. bound steroid after incubation of whole cell monolayers with $\left[{ }^{3} \mathrm{H}\right]$ dihydrotestosterone was similar to that of a control strain (Table II). Thus, in intact cells the binding of $\left[{ }^{3} \mathrm{H}\right]$ dihydrotestosterone by the mutant receptor appeared to be normal, and the intracellular localization of bound $\left[{ }^{3} \mathrm{H}\right]$ dihydrotestosterone was also normal.

Studies in cytosolic extracts. A high-affinity receptor was demonstrated at $0^{\circ} \mathrm{C}$ in molybdate-stabilized cytosol (Fig. 3); the apparent dissociation constant was $0.23 \mathrm{nM}$, and the amount of specific binding was $\sim 15 \mathrm{fmol} / \mathrm{mg}$ protein. A time course study was performed to determine whether the mutant androgen receptor is more rapidly transformed than normal to the DNA-binding state and subsequently degraded (Fig. 4). Although the control and patient fibroblast cytosol contained comparable amounts of $\left[{ }^{3} \mathrm{H}\right]$ dihydrotestosterone binding capacity at $0^{\circ} \mathrm{C}$, $<8 \%$ of the mutant androgen-receptor complexes bound to DNA at each time point after heating to $25^{\circ} \mathrm{C}$. The control cell strain shows a normal time course of transformation (2).

Since a decrease in the binding of mutant $\left[{ }^{3} \mathrm{H}\right]$ dihy- 


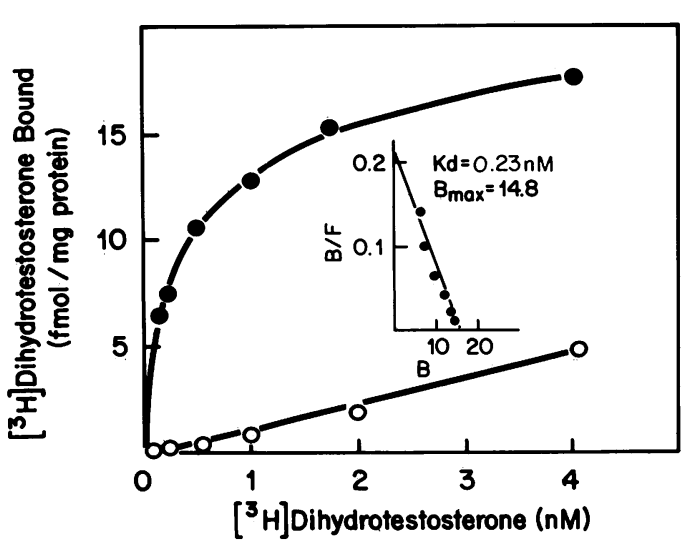

Figure 3. Binding of $\left[{ }^{3} \mathrm{H}\right]$ dihydrotestosterone by mutant cytosol. Aliquots of cytosol $(0.2 \mathrm{ml})$ from fibroblast strain $16(0.6 \mathrm{mg}$ protein/ aliquot) were incubated for $3 \mathrm{~h}$ at $0^{\circ} \mathrm{C}$ with $\left[{ }^{3} \mathrm{H}\right]$ dihydrotestosterone at the indicated concentrations with or without a 500 -fold excess of nonradioactive hormone. After $3 \mathrm{~h}$, binding was assayed by the hydroxylapatite method. $\bullet$, total binding; $\bigcirc$, nonspecific binding. Scatchard analysis of the data is shown in the inset.

drotestosterone-receptor complexes to DNA-cellulose could result either from a defect in a DNA-binding domain of the receptor or from loss of steroid binding capacity under transforming conditions, we reassessed the binding of $\left[{ }^{3} \mathrm{H}\right] \mathrm{di}-$ hydrotestosterone to the mutant receptor after the $25^{\circ} \mathrm{C}$ heating necessary for normal transformation in vitro. Whereas binding in the mutant cells was stable in the presence of molybdate at $0^{\circ} \mathrm{C}$, the amount of $\left[{ }^{3} \mathrm{H}\right]$ dihydrotestosterone bound (as estimated by the gel filtration assay) decreased by $85 \%$ after $60 \mathrm{~min}$ at $25^{\circ} \mathrm{C}$; in contrast, binding in normal cytosol decreased $<15 \%$ during the heating (Fig. 5). The fall in $\left[{ }^{3} \mathrm{H}\right]$ dihydrotestosterone binding by mutant cytosol occurred even in the presence of saturating concentration of hormone. When, after the $25^{\circ} \mathrm{C}$-incubation, the cytosol was again placed at $0^{\circ} \mathrm{C}$ for $3 \mathrm{~h}$ there was no further loss of $\left[{ }^{3} \mathrm{H}\right]$ dihydrotestosterone binding in the mutant, but there was no reversal of the binding loss and no generation of DNA-binding capacity. Similar results were obtained when the hydroxylapatite or charcoal binding assay was used rather than the gel filtration assay (results not shown). No significant metabolism of dihydrotestosterone was detected by thin-layer chromatography during these manipulations (not shown).

The mutant receptor also forms labile complexes with testosterone. A comparison of the transformation of dihydrotestosterone and testosterone-receptor complexes in control and mutant cytosols is shown in Table III. Little DNA-binding capacity is generated with either ligand in the mutant cytosol (10\% of dihydrotestosterone-receptor complexes and no detectable testosterone-receptor complexes bound to DNA). By comparison, $65 \%$ of dihydrotestosterone-receptor complexes and $24 \%$ of testosterone-receptor complexes from the control strain bound to DNA.

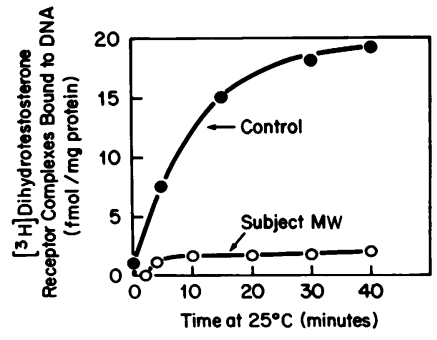

Figure 4. Time course of heatinduced transformation of normal and mutant cytosolic androgen receptors. Cytosols from control (strain 486) and mutant (strain 16) fibroblasts were prepared in TEGM buffer with $1.0 \mathrm{mM}$ sodium molybdate. The samples were incubated for $3 \mathrm{~h}$ at $0^{\circ} \mathrm{C}$ with 3 $\mathrm{nM}\left[{ }^{3} \mathrm{H}\right]$ dihydrotestosterone. A parallel aliquot $(0.2 \mathrm{ml})$ of each was incubated with $\left[{ }^{3} \mathrm{H}\right]$ dihydrotestosterone plus a 500 -fold excess of nonradioactive hormone. Specifically bound $\left[{ }^{3} \mathrm{H}\right]$ dihydrotestosterone was estimated by dextran-charcoal assay after the 3-h incubation. The samples were placed at $25^{\circ} \mathrm{C}, 0.2-\mathrm{ml}$ aliquots were removed at the times indicated, and the amount of transformed receptor was measured by the DNAcellulose method. Control cytosol contained $32 \mathrm{fmol} / \mathrm{mg}$ protein of $\left[{ }^{3} \mathrm{H}\right]$ dihydrotestosterone-receptor complexes at $0^{\circ} \mathrm{C}$; mutant cytosol contained $24.6 \mathrm{fmol} / \mathrm{mg}$ protein of $\left[{ }^{3} \mathrm{H}\right]$ dihydrotestosterone-receptor complexes. Normal cytosol kept at $0^{\circ} \mathrm{C}$ for the course of the experiment contained $<1.5 \mathrm{fmol} / \mathrm{mg}$ protein of transformed hormone-receptor complexes.

On sucrose density gradient centrifugation no dihydrotestosterone binding peak was identified in the mutant under a variety of conditions. The same result was obtained whether the sucrose gradient was in TEGM buffer alone or contained $10 \mathrm{mM} \mathrm{Na}_{2} \mathrm{MoO}_{4}$ or $0.3 \mathrm{M} \mathrm{KCl}$, additions that cause size shifts of the normal fibroblast androgen receptor (Fig. 6, $A, B$, and

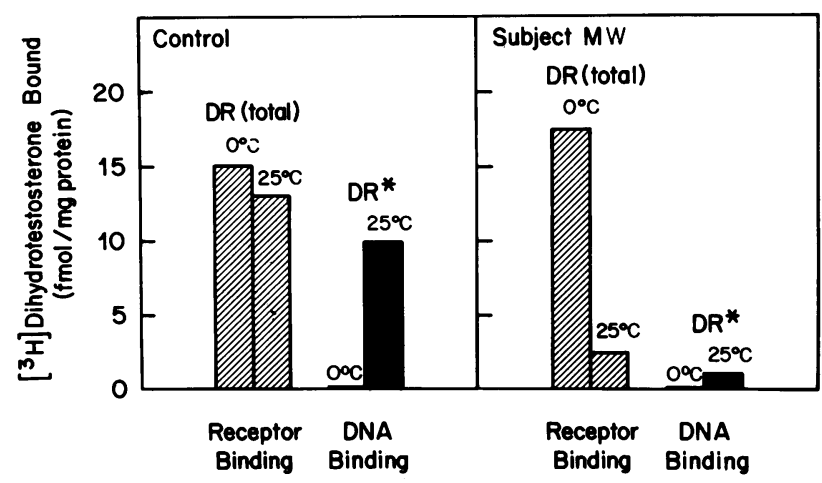

Figure 5. Heat-induced transformation of normal and mutant fibroblast cytosolic $\left[{ }^{3} \mathrm{H}\right]$ dihydrotestosterone-receptor complexes. Cytosols from control fibroblasts (strain 486) and subject MW's fibroblasts (strain 16) were incubated for $3 \mathrm{~h}$ at $0^{\circ} \mathrm{C}$ with $3 \mathrm{nM}$

$\left[{ }^{3} \mathrm{H}\right]$ dihydrotestosterone. Parallel aliquots were incubated with a 500 fold excess of nonradioactive hormone to assess nonspecific binding. After the incubation, $0.2-\mathrm{ml}$ aliquots were assayed for specific $\left[{ }^{3} \mathrm{H}\right]$ dihydrotestosterone binding (DR) by the gel filtration method. The remaining samples were warmed at $25^{\circ} \mathrm{C}$ for $1 \mathrm{~h}$. $0.2-\mathrm{ml}$ aliquots were again taken for estimation of specific

$\left[{ }^{3} \mathrm{H}\right]$ dihydrotestosterone binding (DR) by gel filtration. The amount of transformed receptor-hormone complexes $\left(\mathrm{DR}^{*}\right)$ was assayed in 0.2-ml aliquots of cytosol by the DNA-cellulose binding assay. 
Table III. Comparison of the Transformation of Dihydrotestosterone and Testosterone-receptor Complexes to the DNA-binding State in Control and Mutant Cytosol

\begin{tabular}{|c|c|c|c|c|}
\hline Strain & Ligand & Bs $\left(0^{\circ} \mathrm{C}\right)$ & Bs $\left(25^{\circ} \mathrm{C}\right)$ & $\begin{array}{l}\text { DNA- } \\
\text { cellulose } \\
\text { binding }\end{array}$ \\
\hline & & $\begin{array}{l}\mathrm{fmol} / \mathrm{mg} \\
\text { protein }\end{array}$ & \multicolumn{2}{|c|}{$\begin{array}{l}\% \text { of Bs } \\
\left(0^{\circ} \mathrm{C}\right) \text { value }\end{array}$} \\
\hline Control (486) & {$\left[{ }^{3} \mathrm{H}\right]$ dihydrotestosterone } & 20.0 & 73 & 65 \\
\hline Control (486) & {$\left[{ }^{3} \mathrm{H}\right]$ testosterone } & 26.0 & 24 & 24 \\
\hline Mutant (16) & {$\left[{ }^{3} \mathrm{H}\right]$ dihydrotestosterone } & 10.0 & 36 & 10 \\
\hline Mutant (16) & {$\left[{ }^{3} \mathrm{H}\right]$ testosterone } & 7.5 & 16 & 0 \\
\hline
\end{tabular}

Cytosols from control (strain 486) and mutant (strain 16) fibroblasts were prepared and incubated at $0^{\circ} \mathrm{C}$ for $3 \mathrm{~h}$ with either 1.5 $\mathrm{nM}\left[{ }^{3} \mathrm{H}\right]$ dihydrotestosterone or $15 \mathrm{nM}\left[{ }^{3} \mathrm{H}\right]$ testosterone. Parallel incubations contained a 500-fold excess of nonradioactive hormone to assess nonspecific binding. Specifically bound hormone was then estimated by the hydroxylapatite method $\left(B s 0^{\circ} \mathrm{C}\right)$. The samples were then warmed at $25^{\circ} \mathrm{C}$ for $1 \mathrm{~h}$, and the hydroxylapatite assay was repeated (Bs $25^{\circ} \mathrm{C}$ ). Transformed hormone-receptor complexes were measured by the DNA-cellulose binding assay. Specific binding at $0^{\circ} \mathrm{C}\left(\mathrm{Bs} 0^{\circ} \mathrm{C}\right)$ is expressed as femtomole per milligram protein. The binding after heating (Bs $25^{\circ} \mathrm{C}$ ) and the DNA-cellulose binding are expressed as percentages of that value.

C). Even when the gradients themselves contained $3 \mathrm{nM}$ $\left[{ }^{3} \mathrm{H}\right]$ dihydrotestosterone as well as molybdate and each fraction of the gradient was subsequently treated with hydroxylapatite to separate bound from free hormone, there was no demonstrable receptor peak in sucrose density gradients with the mutant cytosol (Fig. $6 \mathrm{D}$ ).

Mixing experiments were performed to determine whether the lability under transforming conditions was intrinsic to the receptor, due to destructive factors present in the mutant cytosol, or the consequence of a deficiency of some protective factor normally present (Table IV). No alteration in the DNA-binding capacity of hormone-receptor complexes from either mutant or normal cytosol resulted from admixture. The defect, therefore, appears to be intrinsic to the receptor molecule itself.

The instability of the mutant receptor's interaction with dihydrotestosterone appears to be due to susceptibility to proteolytic degradation under transforming conditions. A number of protease inhibitors were tested for their ability to prevent degradation of the mutant hormone-receptor complex at $25^{\circ} \mathrm{C}$. No effect was seen with aprotinin ( 1 trypsin inhibitor unit $/ \mathrm{ml}$ ), phenylmethylsulfonyl fluoride $(1 \mathrm{mM})$, pepstatin $(10 \mu \mathrm{M})$, or bacitracin $(0.1 \mathrm{mM})$ (data not shown).

Leupeptin, however, stabilized the hormone-receptor complexes completely at $25^{\circ} \mathrm{C}$ (Table V) and was effective at concentrations as low as $0.25 \mu \mathrm{M}$. In two control cell strains (486 and 62 ), leupeptin had only minor effects on the dihydrotestosterone-receptor complex concentration either at $0^{\circ}$ or after $25^{\circ} \mathrm{C}$ incubation, whereas it inhibited the degradation of the mutant receptor (strain 16 ) at $25^{\circ} \mathrm{C}$. In addition, leupeptin prevented heat lability of testosterone-receptor complexes from normal cells. At the lowest effective concentration of leupeptin, the amount of receptor binding to DNA after the $25^{\circ} \mathrm{C}$-incubation was increased for the mutant receptor but decreased in the control cell strains. We found no concentration of leupeptin that stabilized the mutant receptors but allowed completely normal DNA binding in the normal strains. Therefore, although degradation of the mutant receptor at $25^{\circ} \mathrm{C}$ can be prevented by leupeptin, the failure to restore transformation of the mutant androgen-receptor complex to normal may be due to some undefined action of leupeptin rather than an intrinsic inability of the mutant to undergo transformation. On sucrose density gradient centrifugation, a small peak of dihydrotestosterone binding was seen in the $7.5 \mathrm{~S}$ region when $250 \mu \mathrm{M}$ leupeptin was included in both cytosol and gradient (results not shown).

\section{Discussion}

The subjects described here appear to have an uncommon defect of the androgen receptor. Dihydrotesterone binding and intracellular localization of dihydrotestosterone are normal in intact

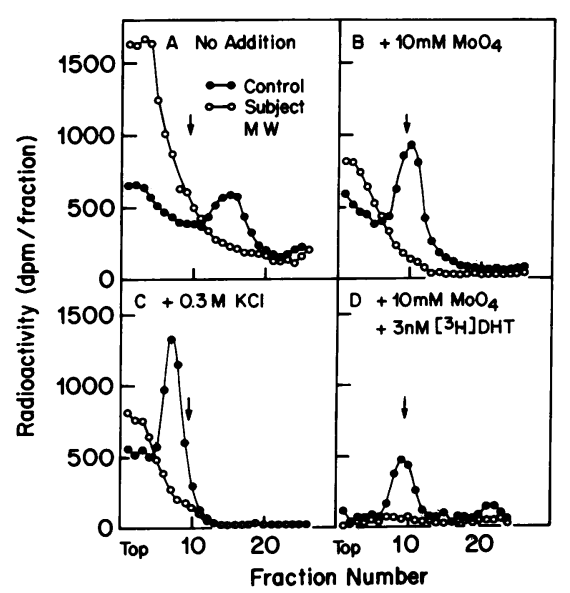

Figure 6. Sucrose density gradient centrifugation of normal and mutant $\left[{ }^{3} \mathrm{H}\right]$ dihydrotestosterone-receptor complexes. Cytosol from control fibroblasts (strain 486) and cytosol from cell strain 16 fibroblasts were prepared in TEGM buffer containing $5 \mathrm{mM}$ sodium molybdate. The samples were incubated for $3 \mathrm{~h}$ at $0^{\circ} \mathrm{C}$ with $3 \mathrm{nM}$

$\left[{ }^{3} \mathrm{H}\right]$ dihydrotestosterone. In $A, B$, and $C$ the samples were charcoaltreated ( $50 \mu \mathrm{l}$ of dextran-charcoal slurry per $0.2-\mathrm{ml}$ aliquot) and layered on $4.9-\mathrm{ml}$ gradients of $5-20 \%$ sucrose in TEGM with either no additions $(A), 10 \mathrm{mM}$ sodium molybdate $(B)$, or $0.3 \mathrm{M} \mathrm{KCI}(C)$. The gradients were centrifuged and fractionated as in the text. In $D$ the sucrose gradients contained $3 \mathrm{nM}\left[{ }^{3} \mathrm{H}\right]$ dihydrotestosterone as well as $10 \mathrm{mM} \mathrm{Na}_{2} \mathrm{MoO}_{4}$; samples of cytosol $(0.2 \mathrm{ml})$ were layered on the gradient after incubation for $3 \mathrm{~h}$ at $0^{\circ} \mathrm{C}$ with $3 \mathrm{nM}$

$\left[{ }^{3} \mathrm{H}\right]$ dihydrotestosterone and without charcoal treatment. After centrifugation the gradients were fractionated, and each fraction was assayed for bound radioactivity by the hydroxylapatite method. DHT, dihydrotestosterone. 
Table IV. Effect of Mixing Control and Mutant Cytosol on the Binding of $\left[{ }^{3} \mathrm{H}\right]$ Dihydrotestosterone-receptor Complex to DNA-Cellulose

\begin{tabular}{|c|c|c|}
\hline \multicolumn{2}{|c|}{ Preincubation of cytosol } & \multirow[b]{2}{*}{$\begin{array}{l}{\left[{ }^{3} \mathrm{H} \text { ]Dihydrotestosterone- }\right.} \\
\text { receptor complex binding } \\
\text { to DNA-cellulose after } \\
25^{\circ} \mathrm{C} \text { incubation (fmol) }\end{array}$} \\
\hline $\begin{array}{l}{\left[{ }^{3} \mathrm{H}\right] \text { Dihydrotestosterone }} \\
\text { (3 nM) }\end{array}$ & $\begin{array}{l}\text { Nonradioactive } \\
\text { dihydrotestosterone } \\
(3 \mathrm{nM})\end{array}$ & \\
\hline Control & None & 8.1 \\
\hline Mutant & None & 0 \\
\hline Control & Mutant & 7.7 \\
\hline Mutant & Control & 0.7 \\
\hline
\end{tabular}

Aliquots of cytosol from the control strain $457(0.2 \mathrm{ml}$ containing $0.39 \mathrm{mg}$ protein) or from the mutant strain $16(0.2 \mathrm{ml}$ containing $0.23 \mathrm{mg}$ protein) were incubated with $3 \mathrm{nM}\left[{ }^{3} \mathrm{H}\right]$ dihydrotestosterone or $3 \mathrm{nM}$ nonradioactive dihydrotestosterone for $3 \mathrm{~h}$ at $0^{\circ} \mathrm{C}$. The $\left[{ }^{3} \mathrm{H}\right]$ dihydrotestosterone-labeled cytosol or mixtures of radioactive and nonradioactive cytosols were then incubated at $25^{\circ} \mathrm{C}$ for $1 \mathrm{~h}$, and binding to DNA-cellulose was assessed as described in the text.

fibroblasts, and no thermolability of binding was demonstrated in intact cells. Cytosol extracts show a high-affinity saturable binding of $\left[{ }^{3} \mathrm{H}\right]$ dihydrotestosterone at $0^{\circ} \mathrm{C}$, but the binding is unstable on sucrose density gradient centrifugation and after heating to $25^{\circ} \mathrm{C}$. While instability on sucrose gradients has been previously recognized as a marker of structurally abnormal androgen receptors (5), the functional significance of this marker is unknown. By studying the transformation of androgen-receptor complexes to the DNA-binding state we have been able to detect a functional defect of androgen receptor in this family coincident with the evidence of qualitative abnormality.
The defect was not observed in fibroblasts from other patients with incomplete testicular feminization (strains 18 and 79) or with the Reifenstein syndrome (strain 500), whose fibroblasts have measurable qualities of androgen receptor, a finding that emphasizes the heterogeneity of molecular defects in the syndromes of androgen resistance. Similarly, the presence of a marker of a qualitative abnormality of the androgen receptor, namely failure of molybdate stabilization on sucrose gradients (as in strain 500), does not necessarily imply a concomitant defect in transformation of the cytosolic androgen receptor.

The nature of the process by which steroid hormone-receptor complexes acquire the capacity to bind to nuclear components is unknown. Nuclear localization studies after whole cells are exposed to radiolabeled hormone have been used to identify mutations of the glucocorticoid receptor in cultured lymphoid cell lines (12), and impaired nuclear retention of androgen has been described by Eil (13) in fibroblasts from patients with androgen resistance. However, normal localization of the hormone in nuclei from intact cells, as occurred in this patient, does not necessarily imply that the steroid-receptor complex is bound to DNA or other nuclear components and could be a passive reflection of the amount of steroid-receptor complex in the cytosol (7). The use of broken cell techniques, wherein androgen-receptor complexes are prepared in a uniform nontransformed state and then reacted under standard conditions to yield transformed complexes, did provide evidence of a defect in this subject's receptor. Kaufman et al. (14) have also reported normal nuclear localization in an individual believed on indirect grounds to also have defective transformation to the DNAbinding state.

The defect delineated in our subject appears similar to that described in glucocorticoid-resistant lymphoid cell lines by

Table V. Effect of Leupeptin on Stabilization of Androgen-receptor Complexes and Their Transformation to the DNA-binding State

\begin{tabular}{llllll}
\hline Strain & {$\left[{ }^{3} \mathrm{H}\right]$ Ligand } & Leupeptin & Bs $0^{\circ} \mathrm{C}$ & Bs $25^{\circ} \mathrm{C}$ & DNA-cellulose binding \\
\hline & & $0.25 \mu M$ & fmol/mg protein & \% of $B s\left(0^{\circ} \mathrm{C}\right)$ value \\
Control (62) & Dihydrotestosterone & - & 17.7 & 78 & 76 \\
Control (62) & Dihydrotestosterone & + & 16.1 & 100 & 40 \\
Control (486) & Dihydrotestosterone & - & 23.7 & 82 & 55 \\
Control (486) & Dihydrotestosterone & + & 26.0 & 100 & 37 \\
Control (486) & Testosterone & - & 37 & 24 & 16 \\
Control (486) & Testosterone & + & 44 & 94 & 29 \\
Mutant (16) & Dihydrotestosterone & - & 14.2 & 37 & 10 \\
Mutant (16) & Dihydrotestosterone & + & 14.3 & 96 & 15
\end{tabular}

Fibroblasts cytosol from control (strains 486 and 62) and subject MW (strain 16) were prepared as described except for the addition of $0.25 \mu \mathrm{M}$ leupeptin to some homogenates. The cytosol was incubated for 3 hours at $0^{\circ} \mathrm{C}$ with either $1.5 \mathrm{nM}\left[{ }^{3} \mathrm{H}\right]$ dihydrotestosterone or $15 \mathrm{nM}$ $\left[{ }^{3} \mathrm{H}\right]$ testosterone. Parallel incubations contained a 500 -fold excess of non-radioactive hormone to estimate non-specific binding. Specifically bound hormone $\left(\mathrm{Bs} 0^{\circ} \mathrm{C}\right.$ ) was then assessed by the hydroxylapatite method. The samples were then heated at $25^{\circ} \mathrm{C}$ for 1 hour, and the hydroxylapatite assay was repeated (Bs $25^{\circ} \mathrm{C}$ ). The transformation of hormone-receptor complexes was measured by DNA-cellulose binding assay. Specific binding at $0^{\circ} \mathrm{C}$ is expressed as $\mathrm{fmol} / \mathrm{mg}$ protein. The binding after heating (Bs $25^{\circ} \mathrm{C}$ ) and DNA-cellulose binding are expressed as percentages of that value. 
Schmidt et al. (15). The receptor is normal in amount and shows normal kinetics of ligand binding under standardized nontransforming conditions. However, under conditions that uniformly result in transformation in other cell lines, the mutant receptorhormone complex is labile. No DNA-binding capacity is generated, and steroid binding activity is lost.

This defect is probably intrinsic to the receptor molecule itself, since the presence of an abnormal destructive factor operative at higher temperatures should have affected the normal receptor in the mixing experiment. Conversely, no evidence was adduced for the absence of a stabilizing factor since normal cytosol did not correct the defective transformation of mutant receptors.

Experiments with the protease inhibitor leupeptin suggest that under transforming conditions the mutant receptor is susceptible to an endogenous protease in fibroblast cytosol. Since leupeptin both stabilizes the total amount of mutant receptor and increases the amount of transformed mutant receptor measurable, it seems likely that transformation of the mutant hormone-receptor complex exposes a protease-sensitive site on the protein. Degradation could then result in loss of steroid-binding capacity. Sherman et al. (16) have reported that leupeptin prevents degradation of a $10.5 \mathrm{~S}$ species of the estrogen receptor from human breast cancers. Similarly, use of leupeptin permitted the detection of a small amount of the mutant androgen receptor on sucrose density gradient centrifugation in the present study. Interestingly, we observed that the lability of testosterone-receptor complexes from normal cytosol was also corrected with leupeptin. Thus, the interaction of testosterone with the normal receptor does not confer the same degree of protease resistance as does dihydrotestosterone binding. As noted earlier, we cannot exclude the possibility that leupeptin's effect may involve mechanisms other than inhibition of proteolysis.

These studies provide some perspective on the nature of the molecular defects in subjects with measurable amounts of androgen receptor despite clear evidence of androgen resistance. These disorders have been categorized into two groups: those in whom no abnormality has been identified and a group of patients in whom indirect evidence has been ascertained for a mutation that affects the structure of the androgen receptor (5, 6). However, the previous studies have been limited to methods of assessing the binding of ligand to receptors. The present technique was utilized in the belief that it might provide insight into the subsequent phases of androgen-receptor complex action. However, in examining "receptor-positive" mutations of both types we found only two cousins in whom the defect impairs the generation of DNA-binding capacity. In these subjects a receptor with a known marker of qualitative abnormality was shown to form hormone-receptor complexes that are unstable under transforming conditions. No pure defect in DNA-binding capacity was found. Such mutations that affect a DNA-binding site of the receptor but not the steroid-binding site may be rare. However, since our assay system uses heterologous DNA and provides best results using denatured DNA (2), it seems clear that we are studying a nonspecific and possibly low-affinity interaction. This experimental method obviously lacks the sensitivity to detect alterations that selectively impair high-affinity binding of hormone-receptor complexes to specific segments of the genome. Investigation of such disorders, as have been achieved in the glucocorticoid and progesterone receptor systems $(17,18,19)$, will require the availability of cloned DNA sequences involved in the regulation of the transcription of specific messenger RNAs induced by the action of androgens.

The data presented here also bear on two related and unresolved problems in androgen physiology. The first has to do with the pathogenesis of syndromes of incomplete androgen resistance. Both embryologic data and study of the $5 \alpha$-reductase deficiency have provided evidence that the action of testosterone alone is needed for differentiation of the embryonic wolffian duct into vas deferens, seminal vesicle, and epididymis, whereas dihydrotestosterone is required for virilization of the external genitalia (1). The clinical phenotypes of the X-linked syndromes of incomplete androgen resistance cover a spectrum, but in general suggest that dihydrotestosterone-mediated events are more severely impaired than testosterone-mediated processes (e.g., wolffian duct virilization appears to be more normal than the virilization of the external genitalia). This type of androgen resistance is associated with defects in the androgen receptor (5), but, since both testosterone and dihydrotestosterone bind to the same receptor $(1,20,21)$ it has been difficult to formulate plausible mechanisms whereby the action of one ligand is selectively impaired. The second (and more general) question is why dihydrotestosterone is necessary for androgen action in some target tissues while testosterone mediates male differentiation in others.

The unexpected finding of transformation-lability of testosterone-receptor complexes of control cells and from cells of a patient whose phenotype indicates adequate testosterone effect during embryogenesis suggests that this action of the hormone in target tissues may be less critically dependent on generation of a stable transformed hormone-receptor complex. The proximity of the testis to the wolffian duct may result in greater local intracellular androgen concentrations, or some other local factors in these target tissues may serve to reinforce an otherwise weak androgenic signal.

Dihydrotestosterone, in addition to its higher binding affinity for the nontransformed receptor, was found to form a more stable DNA-binding complex with the normal receptor. These amplifying effects may be necessary for efficient transmission of the androgenic signal at sites distant from the sources of hormone. The mutation described here, in which phenotypic evidence of defective action of dihydrotestosterone at target tissues is associated with in vitro evidence for transformationlabile dihydrotestosterone-receptor complexes, supports this construction.

This formulation suggests one explanation of how a mutation involving a single receptor protein could impair to a different degree the actions of two different ligands of the same receptor. 
Further studies of patients with androgen resistance will be necessary to determine whether transformation lability in vitro does indeed have functional significance or is only a new qualitative marker of altered androgen receptor structure.

\section{Acknowledgments}

We wish to acknowledge the able technical assistance of Diane R. Allman. Brenda Hennis and Carolyn Garner provided excellent secretarial assistance.

This work was aided by grant AM03892 from the National Institutes of Health.

\section{References}

1. Griffin, J. E., and J. D. Wilson. 1980. The syndromes of androgen resistance. N. Engl. J. Med. 302:198-209.

2. Kovacs, W., J. E. Griffin, and J. D. Wilson. 1983. Transformation of human androgen receptors to the deoxyribonucleic acid-binding state. Endocrinology. 113:1574-1581.

3. Grody, W., W. T. Schrader, and B. W. O'Malley. 1982. Activation, transformation and subunit structure of steroid hormone receptors. Endocr. Rev. 3:141-163.

4. Griffin, J. E., K. Punyashthiti, and J. D. Wilson. 1976. Dihydrotestosterone binding by cultured human fibroblasts. Comparison of cells from control subjects and from patients with hereditary male pseudohermaphroditism due to androgen resistance. J. Clin. Invest. 57:13421351.

5. Griffin, J. E., and J. L. Durrant. 1982. Qualitative receptor defects in families with androgen resistance: failure of stabilization of the fibroblast cytosol androgen receptor. J. Clin. Endocrinol. Metab. 55:465474.

6. Griffin, J. E. 1979. Testicular feminization associated with a thermolabile androgen receptor in cultured human fibroblasts. J. Clin. Invest. 64:1624-1631.

7. Collier, M. E., J. E. Griffin, and J. D. Wilson. 1978. Intranuclear binding of $\left[{ }^{3} \mathrm{H}\right]$ dihydrotestosterone by cultured human fibroblasts. $E n$ docrinology. 103:1499-1505.

8. Kissane, J. M., and E. Robbins. 1958. The fluorometric measurement of deoxyribonucleic acid in animal tissue with special reference to the central nervous system. J. Biol. Chem. 233:184-188.
9. Lowry, O. H., N. J. Rosebrough, A. L. Farr, and R. J. Randall. 1951. Protein measurement with folin phenol reagent. J. Biol. Chem. 193-265-275.

10. Montelaro, R. C., and R. R. Rueckert. 1975. Radio-labelling of proteins and viruses in vitro by acetylation with radioactive acetic anhydride. J. Biol. Chem. 250:1413-1421.

11. Alberts, B., and G. Herrick. 1971. DNA cellulose chromatography. Methods Enzymol. 11:198-217.

12. Yamamoto, K. R., M. R. Stampfer, and G. M. Tomkins. 1974. Receptors from glucocorticoid-sensitive lymphoma cells and two classes of insensitive clones: physical and DNA-binding properties. Proc. Natl. Acad. Sci. USA. 71:3901-3905.

13. Eil, C. 1983. Familial incomplete male pseudohermaphroditism associated with impaired nuclear androgen retention. J. Clin. Invest. 71:850-858.

14. Kaufman, M., L. Pinsky, L. Simard, and S. C. Wong. 1982. Defective activation of androgen-receptor complexes. A marker of androgen insensitivity. Mol. Cell. Endocr. 25:151-162.

15. Schmidt, T. J., J. M. Harmon, and E. B. Thompson. 1980. 'Activation-labile' glucocorticoid-receptor complexes of a steroid resistant variant of CEM-C7 human lymphoid cells. Nature (Lond.). 286:507510 .

16. Sherman, M. R., F. B. Tuazon, and L. K. Miller. 1980. Estrogen receptor cleavage and plasminogen activation by enzymes in human breast tumor cytosol. Endocrinology. 106:1715-1727.

17. Payvar, F., O. Wrange, J. Carlstedt-Duke, S. Okret, J. A. Gustafsson, and K. Yamamoto. 1981. Purified glucocorticoid receptors bind selectively in vitro to a cloned DNA fragment whose transcription is regulated by glucocorticoids in vivo. Proc. Natl. Acad. Sci. USA. 78:66286632.

18. Pfahl, M. 1982. Specific binding of the glucocorticoid-receptor complex to the mouse mammary tumor proviral promoter region. Cell. 31:475-482.

19. Hughes, M. R., J. G. Compton, W. T. Schrader, and B. W. O'Malley. 1981. Interaction of the chick oviduct progesterone receptor with deoxyribonucleic acid. Biochemistry. 20:2481-2491.

20. Wilbert, D. M., J. E. Griffin, and J. D. Wilson. 1983. Characterization of the cytosol androgen receptor of the human prostate. $J$. Clin. Endocrinol. Metab. 56:113-120.

21. Maes, M., S. Sultan, N. Zerhouni, S. W. Rothwell, and C. J. Migeon. 1979. Role of testosterone binding to the androgen receptor in male sexual differentiation of patients with $5 \alpha$-reductase deficiency. J. Steroid Biochem. 11:1385-1390. 